\title{
Assessment of Airborne Bacteria and Fungi in Different Home Environments
}

\author{
Seda Naz Sarıca ${ }^{*}$, Ayşe Bodur ${ }^{2}$, Özlem Özden Üzmez ${ }^{3}$, Semra Malkoç${ }^{4}$

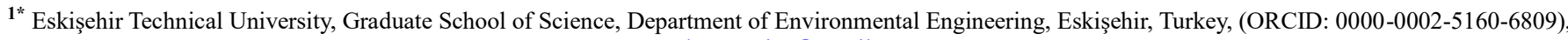 \\ sedanazsarica@gmail.com \\ ${ }^{2}$ Eskişehir Technical University, Faculty of Engineering, Department of Environmental Engineering, Eskişehir,Turkey, (ORCID: 0000-0002-6781-8363), \\ aysebdr5@gmail.com \\ ${ }^{3}$ Eskişehir Technical University, Faculty of Engineering, Department of Environmental Engineering, Eskişehir,Turkey, (ORCID: 0000-0003-4310-788X), \\ oozden@eskisehir.edu.tr \\ ${ }^{4}$ Eskişehir Technical University, Faculty of Engineering, Department of Environmental Engineering, Eskişehir,Turkey, (ORCID: 0000-0002-8092-411X), \\ satik@eskisehir.edu.tr
}

(1st International Conference on Applied Engineering and Natural Sciences ICAENS 2021, November 1-3, 2021)

(DOI: 10.31590/ejosat.1014717)

ATIF/REFERENCE: Sarıca, S. N., Bodur, A., Özden Üzmez, Ö., Malkoç, S. (2021). Assessment of Airborne Bacteria and Fungi in Different Home Environments. European Journal of Science and Technology, (28), 1237-1245.

\begin{abstract}
The aim of this study is to evaluate the concentrations of bacteria and fungi in different indoor environments (living area, bedroom, kitchen, bathroom, hallway) of three selected homes in Eskişehir, Turkey. In each home, one-hour measurements were performed in both midday and evening hours of a day. Measurement studies were carried out by passive method and were repeated in three sea sons as winter, spring and summer in the year of 2021. Indoor/Outdoor ratios (I/O) for bacteria and fungi were calculated by using simultaneous indoor and outdoor measurement results to evaluate the effect of outdoor air on indoor air. The concentrations of bacteria and fungi aerosols in the various indoor environments of three homes ranged between $1.00-1889.37 \mathrm{CFU} / \mathrm{m}^{3}$. In general, the results were between "low" and "high" pollution degrees when compared with European Commission standards. The highest I/O ratio for bacteria was found in the bathroom of Home 3 in the summer-evening measurement period while the highest I/O fungi ratio was obtained in the hallway of Home 1 in the winter-evening period. When the relationship between bacteria and fungi concentrations measured in different seasons was investigated, weak relationship was observed in all seasons except winter season at Home 1 and spring season at Home 2. Both seasonal variations and characteristics of the home environments were observed to have an effect on the indoor bacterial and fungal concentrations.
\end{abstract}

Keywords: Bacteria, Fungi, Home Environment, Indoor Air Quality, Microbiological Assessment.

\section{Farklı Ev Ortamlarında Havadaki Bakteri ve Mantarların Değerlendirilmesi}

$\ddot{O} \mathbf{z}$

Bu çalışmanın amacı, Türkiye Eskişehir'de seçilen üç evin farklı iç ortamlarındaki (yaşam alanı, yatak odası, mutfak, banyo, koridor) bakteri ve mantar konsantrasyonlarını değerlendirmektir. Her evde, günün hem öğle hem de akşam saatlerinde birer saatlik ölçümler yapılmıştır. Ölçüm çalışmaları pasif yöntemle yapılmış ve 2021 yılında kış, ilkbahar ve yaz olmak üzere üç mevsimde tekrarlanmıştır. Dış ortam havasının iç ortam havası üzerindeki etkisini değerlendirmek üzere, eş zamanlı gerçekleştirilen iç ve dış ortam ölçüm sonuçları kullanılarak bakteri ve mantar için İç/Dış ortam oranları (İ/D) hesaplanmıştır. Üç evin çeşitli iç ortamlarındaki bakteri ve mantar aerosollerinin konsantrasyonları 1,00 - 1889,37 CFU $/ \mathrm{m}^{3}$ arasında değişmektedir. Genel olarak, elde dilen sonuçlar Avrupa Komisyonu standartlarıyla karşılaştırıldığında "düşük" ve "yüksek” kirlilik seviyeleri arasında yer almaktadır. Bakteriler için en yüksek İ/D oranı yaz akşamı ölçüm periyodunda Ev 3'ün banyosunda, en yüksek I/D mantar oranı ise kış akşamı periyodunda Ev 1'in koridorunda elde edilmiştir. Farklı mevsimlerde ölçülen bakteri ve mantar konsantrasyonları arasındaki ilişski incelendiğinde, Ev 1'de kış mevsimi ve Ev 2'de ilkbahar mevsimi hariç tüm mevsimlerde zayıf bir ilişki gözlenmiştir. Hem mevsimsel değişimlerin, hem de ev ortamlarının özelliklerinin iç mekan bakteri ve mantar konsantrasyonları üzerinde etkisi olduğu gözlemlenmiştir.

Anahtar Kelimeler: Bakteri, Mantar, Ev Ortamı, İç Ortam Hava Kalitesi, Mikrobiyal Değerlendirme.

* Corresponding Author: sedanazsarica@gmail.com 


\section{Introduction}

Indoor air quality is a significant concern due to the amount of time spent indoors. Some studies showed that people living in urban environments spend an average of $87 \%$ of their time indoors (Diffey, 2011; Klepeis et al., 2001; WHO, 2009). World Health Organization (WHO) states that indoor air quality becomes significantly more important as the time people spend in buildings increases. Many problems related to indoor air quality are accepted as important risk factors for human health in developed countries as well as in developing countries. Changes in indoor air quality in residences, nursing homes, hospitals, schools and other private settings affect population groups that are particularly vulnerable due to their health status or age (WHO, 2008). It is estimated that the time spent indoors will be more and more, and therefore diseases will increase. Women who spend most of the day by breathing the fuels used for heating, cooking in stoves with insufficient ventilation, and also babies and children are more exposed to the negative effects of indoor air pollution (Demirel et al., 2014). Some precautions such as good ventilation of the indoor environments (for example; kitchens and bathrooms), ventilation of fabrics and clothing, frequent cleaning of water in air conditioners and refrigerators, keeping carpets clean and dry, frequent dusting of furniture and walls should be taken to reduce indoor air problems (Aghlara, 2017; Gönüllü et al., 2002).

Bioaerosols, which are among the important air pollutants, are generally defined as microbial particulate matter, aerosols of plant or animal origin. Pathogenic and non-pathogenic live or dead bacteria, fungi, viruses are included in this class. They also produce allergens, irritants and harmful chemicals such as endotoxin and mycotoxin (Nazaroff, 2016). The share of bioaerosols in indoor air pollution is 5-34\% (Shiaka \& Yakubu, 2013). According to the Environmental Protection Agency (EPA) data, it has been documented that the pollutants that people are exposed to indoors are 2-5 times and sometimes 100 times higher than the pollutants they are exposed to outdoors (Agle \& Galbraith, 1991). Airborne aerosols are one of the subjects that have been studied extensively in recent years due to the health problems they cause (Demirel et al., 2014; Fabian et al., 2005; Lee et al., 2012; Stetzenbach, 1998). Microbes present in high amounts in the air cause asthma, allergic rhinitis, hypersensitive pneumonia, sick building syndrome, infection and toxic effects (Agle \& Galbraith, 1991; Stetzenbach, 1998). In non-industrial indoor environments, the most important source of airborne bacteria is human activities (Fabian et al., 2005; Lee et al., 2012). The temperature and relative humidity of the air is also effective on the growth of airborne bacteria (Ren et al., 2001; Siersted \& Gravesen, 1993).

Many scientists investigating indoor air pollution have conducted studies in various micro-environments such as residence, entertainment centre, pet shop, shopping centre, primary school and kindergarten (Alwakeel, 2008; Fabian et al., 2005; Hu et al., 2014; Jones \& Cookson, 1983; Lee et al., 2002; Menteşe et al., 2013; Yassin \& Almouqatea, 2010).

In this study, three homes having different outdoor locations and indoor characteristics were selected in Eskişehir, Turkey. Indoor bacteria and fungi measurement studies were performed in five various microenvironments such as hallway, living room, bedroom, kitchen and bathroom in each home. In addition to indoor measurement studies, outdoor measurements were also carried out simultaneously to evaluate the effect of outdoor air on indoor air and to determine indoor/outdoor (I/O) ratios for bacteria and fungi. These ratios were calculated for each indoor environment. Measurement studies were repeated in three seasons as winter, spring and summer.

\section{Material and Method}

\subsection{Characteristics of the Selected Homes}

In this study, indoor and outdoor bacteria and fungi concentrations were measured in three selected homes in Eskişehir, Turkey. Some parameters such as the number of people living and working at homes, the size and locations of the homes, the number of the rooms were considered while choosing homes. Hourly measurements were carried out in the living area, bedroom, kitchen, bathroom and hallway at each home. The Google Earth view of the homes included in the study is shown in Figure 1.

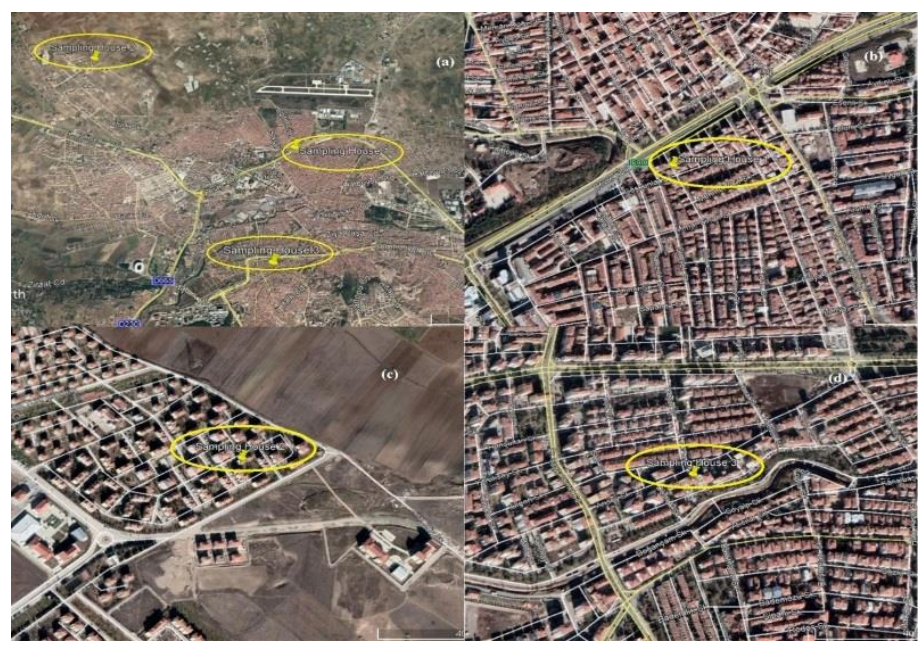

Figure 1. The homes included in the study: (a) Google Earth image showing three selected homes. (b) The location of the first home (Home 1) in Bahçelievler neighborhood. (c) The location of the second home (Home 2) in Aşağı Sögütönü neighborhood.

(d) The location of the third home (Home 3) in Akarbaşl neighborhood.

Home 1 is located in the city center and urban residential area. It is directly affected by the traffic and population density and also $50 \mathrm{~m}$ away from Eskişehir (E90-D200) belt highway. This home is located on the 4th floor of a 4-storey apartment building. The number of the people living in this home is three and two of them are actively going to work. It has an average area of $85 \mathrm{~m}^{2}$ with 3 rooms and natural ventilation (window) and aspirator are used as ventilation system. Home 2 is $10 \mathrm{~km}$ from the city center and located away from traffic and population density (suburban). This home is located on the 1 st floor of a 4-storey apartment building. The number of the people living in this home is four and one is actively working and one is a student (due to the pandemic, she continues distance education from home). The home has an average area of $90 \mathrm{~m}^{2}$ and has 3 rooms. Natural ventilation (window) and aspirator are used as ventilation system. Home 3 is located in an urban residential area in the city. This location has moderate traffic and population density. It is located on the 2 nd floor of a 9-storey apartment building and within walking distance of Eskişehir Göztepe Tram Station and $3 \mathrm{~km}$ from the city center. 
The number of the people living in this home is three. Since one person does not work actively and the remaining two people are students, they spend their whole day at home. This home has 4 rooms and it has an average area of $100 \mathrm{~m}^{2}$. Natural ventilation (window) and aspirator are used for ventilation demand. Specific characteristics of each home are given in Table 1. Also, the floor plans and measurement points of the selected homes are shown in Figure 2.

Table 1. Specific characteristics of the selected homes

\begin{tabular}{|c|c|c|c|c|c|}
\hline Home & $\begin{array}{c}\text { Area of the } \\
\text { Home and } \\
\text { Floor Location }\end{array}$ & Ventilation Type & Measurement Points & Location & $\begin{array}{c}\text { Number of } \\
\text { People Living } \\
\text { in the Home }\end{array}$ \\
\hline Home 1 & $\begin{array}{l}85 \mathrm{~m}^{2} . \text { On the } \\
4^{\text {th }} \text { floor of a } 4- \\
\text { storey building }\end{array}$ & $\begin{array}{c}\text { Aspirator and } \\
\text { natural ventilation }\end{array}$ & $\begin{array}{l}\text { Hallway, living room, } \\
\text { bedroom, kitchen, } \\
\text { bathroom and outdoor }\end{array}$ & $\begin{array}{c}\text { In an urban } \\
\text { residential area. } \\
50 \text { m away from } \\
\text { Eskişehir (E90- } \\
\text { D200) belt } \\
\text { highway. High } \\
\text { population and } \\
\text { traffic density }\end{array}$ & $\begin{array}{l}3 \text { people live in } \\
\text { this home. Two } \\
\text { of them are } \\
\text { actively going } \\
\text { to work }\end{array}$ \\
\hline Home 2 & $\begin{array}{l}90 \mathrm{~m}^{2} . \text { On the } \\
1^{\text {st }} \text { floor of a } 4- \\
\text { storey building }\end{array}$ & $\begin{array}{c}\text { Aspirator and } \\
\text { natural ventilation }\end{array}$ & $\begin{array}{l}\text { Hallway, living room, } \\
\text { bedroom, kitchen, } \\
\text { bathroom and outdoor }\end{array}$ & $\begin{array}{l}\text { In a suburban } \\
\text { area. } 10 \mathrm{~km} \text { from } \\
\text { the city center. } \\
\text { Low population } \\
\text { and traffic density }\end{array}$ & $\begin{array}{l}4 \text { people live in } \\
\text { this home. One } \\
\text { of them is } \\
\text { actively } \\
\text { working and } \\
\text { one of them is } \\
\text { a student }\end{array}$ \\
\hline Home 3 & $\begin{array}{l}100 \mathrm{~m}^{2} . \text { On the } \\
2^{\text {nd }} \text { floor of a 9- } \\
\text { storey building }\end{array}$ & $\begin{array}{c}\text { Aspirator and } \\
\text { natural ventilation }\end{array}$ & $\begin{array}{l}\text { Hallway, living room, } \\
\text { bedroom, kitchen, } \\
\text { bathroom and outdoor }\end{array}$ & $\begin{array}{c}\text { In urban } \\
\text { residential area. } 3 \\
\mathrm{~km} \text { from the city } \\
\text { center. Moderate } \\
\text { traffic and } \\
\text { population density }\end{array}$ & $\begin{array}{l}3 \text { people live in } \\
\text { this home. Two } \\
\text { of them are } \\
\text { student }\end{array}$ \\
\hline
\end{tabular}

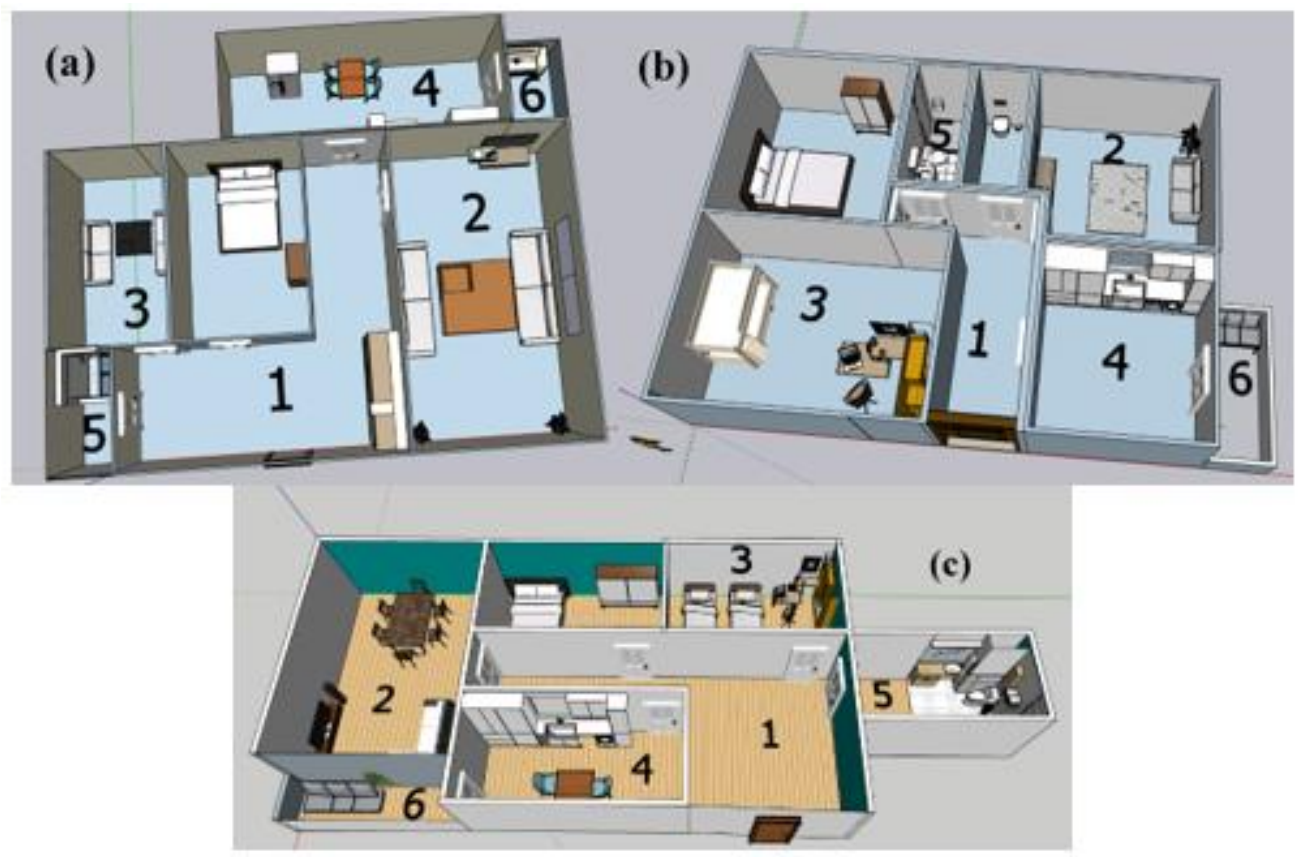

Figure 2. Floor plan and indoor - outdoor measurement points in a) Home 1, b) Home 2, c) Home 3. *1: Hallway, 2: Living Room, 3: Bedroom, 4: Kitchen, 5: Bathroom, 6: Outdoor 


\subsection{Measurement Program and Method}

Microbiological samples were collected for one hour by passive sampling method (Fig. 3). Measurements were performed in the indoor and outdoor environments of three different homes selected in Eskişehir, Turkey (Fig. 3). There was a total of 216 microbiological measurements taken. There were 108 bacteria measurements and 108 fungi measurements. Two samples were taken from each room of the homes. Measurement studies were repeated in three seasons as winter, spring and summer in the year of 2021.

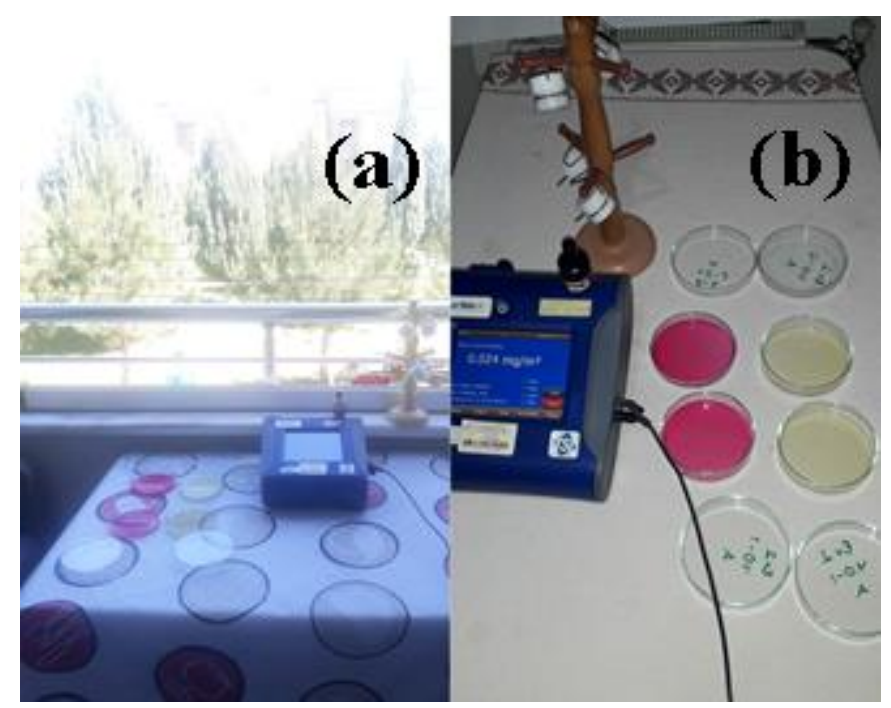

Figure 3. Microbiological measurement studies (a) Home 2 -outdoor, b) Home 2 -indoor

Trypticase Soy Agar was used for total bacteria and chloramphenicol added Sabouraud Dextrose Agar (SDA) was used for total fungi. The growth media were exposed to indoor air and then transferred to the laboratory under suitable conditions and incubated at $37^{\circ} \mathrm{C}$ for 24 hours for bacteria and at $28^{\circ} \mathrm{C}$ for 7 days for fungi. Visual counting was performed after incubation and colony forming units per cubic meter $\left(\mathrm{CFU} / \mathrm{m}^{3}\right)$ were calculated by considering the equation described below (Fekadu \& Getachewu, 2015):

$$
\mathrm{N}=5 \mathrm{a} \times 104(\mathrm{bt})^{-1}
$$

where $\mathrm{N}$ is microbial $\mathrm{CFU} / \mathrm{m}^{3}$ of indoor air, a is number of colonies per petri dish, $\mathrm{b}$ is dish surface area $\left(\mathrm{cm}^{2}\right)$ and $\mathrm{t}$ is exposure time (minutes).

\section{Results and Discussion}

In Table 2 and 3, some statistical values of the measurement results are given. When the midday bacterial results of Home 1 were compared seasonally, the highest concentration was measured in summer ( $991.38 \mathrm{CFU} / \mathrm{m}^{3}$ in hallway). It was found that the highest bacteria concentration measured in the evening period of Home 1 was obtained in winter $\left(1889.37 \mathrm{CFU} / \mathrm{m}^{3}\right.$ in hallway). The reason for high concentrations for both seasons is thought as the active use of the hallway for home entry and exit during measurement hours.

According to results of Home 2, the highest bacterial concentration that was found in winter-midday measurement period was $603.45 \mathrm{CFU} / \mathrm{m}^{3}$ in bedroom. The highest bacterial concentration of the evening period was $610.63 \mathrm{CFU} / \mathrm{m}^{3}$ in the kitchen.

The highest bacteria concentration obtained in the summer (1077.59 CFU $/ \mathrm{m}^{3}$ in bedroom) at Home 3 was measured in the midday period. The maximum concentration of winter season $\left(1379.31 \mathrm{CFU} / \mathrm{m}^{3}\right)$ was measured in the evening period in the living room.

Table 3 shows the seasonal fungi concentrations for three selected homes. The highest concentration $\left(560.34 \mathrm{CFU} / \mathrm{m}^{3}\right.$ in living room) was measured in the midday measurement of spring season at Home 1. In the evening measurements, the highest concentration $\left(452.59 \mathrm{CFU} / \mathrm{m}^{3}\right)$ was measured in the living room similar to the spring season.

Table 4 shows the microbiological air quality standards for indoor environments and also evaluation of the results obtained in this study based on the given standard values. Looking at the results for bacteria in Table 4, "intermediate" and "high" pollution degree levels were obtained for all measurement periods for each home. When the fungi results were examined, lower pollution degrees were obtained (Table 4).

Indoor/Outdoor concentration ratios for bacteria and fungi (I/O) were also calculated for each microenvironment of each home using simultaneous indoor and outdoor measurement results (Table 5). When the $\mathrm{I} / \mathrm{O}$ ratios for bacteria concentrations were evaluated for Home $1,>1$ ratios were obtained in the winterevening measurement (in hallway, bedroom and kitchen), springevening measurement (hallway), summer-midday (hallway) and evening (bathroom) measurements.

Bacteria I/O ratios obtained at Home 2 were $>1$ in the living room and bedroom in the winter-midday measurement, in the hallway and kitchen in the spring-midday and also in the hallway, living room and kitchen in the spring-evening period.

$\mathrm{I} / \mathrm{O}$ ratios obtained for Home 3 were $>1$ in the hallway, living room, bedroom and bathroom in the winter-evening period, spring-midday (kitchen and bathroom) and evening (hallway, bedroom and bathroom) periods and also summer-midday (bedroom) and evening (all indoor microenvironments) periods.

When the fungi I/O ratios were examined, $>1$ ratios were found for only winter-evening period at Home 1 (hallway, living room and bedroom). All I/O ratios were $<1$ for Home 2 for all measurement periods. In Home 3,> $1 \mathrm{I} / \mathrm{O}$ ratios were obtained in the summer-evening measurement period in hallway. 
Table 2. Number of bacteria colony counts (CFU) per $\mathrm{m}^{3}$ air obtained at each home for different seasons. The values are given as min, max, mean and standard deviation (SD)

\begin{tabular}{|c|c|c|c|c|c|c|}
\hline \multirow{2}{*}{$\begin{array}{c}\text { Bacteria Measurement } \\
\text { Results }\left(\mathrm{CFU} / \mathrm{m}^{3}\right)\end{array}$} & \multicolumn{2}{|c|}{ Winter } & \multicolumn{2}{|c|}{ Spring } & \multicolumn{2}{|c|}{ Summer } \\
\hline & Midday & Evening & Midday & Evening & Midday & Evening \\
\hline \multicolumn{7}{|c|}{ Home 1} \\
\hline Minimum & 215.52 & 287.36 & 301.72 & 660.92 & 330.46 & 287.36 \\
\hline Maximum & 502.87 & 1889.37 & 711.21 & 1379.31 & 991.38 & 1314.66 \\
\hline Mean & 362.07 & 899.43 & 522.99 & 992.82 & 563.22 & 603.45 \\
\hline Std. Deviation & 129.57 & 729.71 & 161.23 & 258.14 & 264.47 & 417.63 \\
\hline \multicolumn{7}{|c|}{ Home 2} \\
\hline Minimum & 57.47 & 294.54 & 21.55 & 28.74 & 43.10 & 100.57 \\
\hline Maximum & 603.45 & 610.63 & 215.52 & 280.17 & 373.56 & 510.06 \\
\hline Mean & 281.61 & 412.36 & 100.57 & 123.56 & 191.09 & 320.40 \\
\hline Std. Deviation & 234.74 & 135.41 & 90.01 & 98.29 & 119.95 & 184.25 \\
\hline \multicolumn{7}{|c|}{ Home 3} \\
\hline Minimum & 114.94 & 150.86 & 107.76 & 107.76 & 215.52 & 129.31 \\
\hline Maximum & 186.78 & 1379.31 & 854.89 & 416.67 & 1077.59 & 783.05 \\
\hline Mean & 133.62 & 719.83 & 410.92 & 274.43 & 537.36 & 380.75 \\
\hline Std. Deviation & 30.31 & 479.91 & 294.51 & 147.87 & 360.61 & 259.77 \\
\hline
\end{tabular}

Table 3. Number of fungi colony counts (CFU) per $\mathrm{m}^{3}$ air obtained at each home for different seasons. The values are given as min, max, mean and standard deviation (SD)

\begin{tabular}{|c|c|c|c|c|c|c|}
\hline \multirow{2}{*}{$\begin{array}{c}\text { Fungi Measurement } \\
\text { Results }\left(\text { CFU } / \mathbf{m}^{3}\right)\end{array}$} & \multicolumn{2}{|c|}{ Winter } & \multicolumn{2}{|c|}{ Spring } & \multicolumn{2}{|c|}{ Summer } \\
\hline & Midday & Evening & Midday & Evening & Midday & Evening \\
\hline \multicolumn{7}{|c|}{ Home 1} \\
\hline Minimum & 0.00 & 35.92 & 93.39 & 165.23 & 179.60 & 57.47 \\
\hline Maximum & 64.66 & 143.68 & 560.34 & 452.59 & 301.72 & 237.07 \\
\hline Mean & 34.48 & 77.59 & 297.41 & 298.85 & 225.57 & 160.92 \\
\hline Std. Deviation & 24.57 & 43.52 & 178.05 & 111.71 & 48.88 & 68.83 \\
\hline \multicolumn{7}{|c|}{ Home 2} \\
\hline Minimum & 7.18 & 7.18 & 21.55 & 57.47 & 43.10 & 100.57 \\
\hline Maximum & 100.57 & 165.23 & 1120.69 & 768.68 & 143.68 & 323.28 \\
\hline Mean & 47.42 & 53.16 & 258.62 & 310.34 & 80.46 & 179.60 \\
\hline Std. Deviation & 40.83 & 65.37 & 482.58 & 294.82 & 38.82 & 96.11 \\
\hline \multicolumn{7}{|c|}{ Home 3} \\
\hline Minimum & 0.00 & 14.36 & 21.55 & 35.92 & 57.47 & 43.10 \\
\hline Maximum & 79.03 & 71.84 & 71.84 & 237.07 & 79.02 & 280.17 \\
\hline Mean & 22.99 & 28.73 & 48.85 & 93.39 & 70.40 & 143.68 \\
\hline Std. Deviation & 32.29 & 24.36 & 18.60 & 83.31 & 11.80 & 100.96 \\
\hline
\end{tabular}


Avrupa Bilim ve Teknoloji Dergisi

Table 4. An assessment of air quality in the selected different home indoor environments (Fekadu \& Getachewu, 2015)

\begin{tabular}{|c|c|c|c|c|c|c|c|c|c|c|c|c|c|c|c|c|c|c|c|c|}
\hline \multirow{3}{*}{$\begin{array}{l}\text { Group of } \\
\text { microbes }\end{array}$} & \multirow{3}{*}{$\begin{array}{c}\text { Range of } \\
\text { values } \\
\left(\mathrm{CFU} / \mathrm{m}^{3}\right)\end{array}$} & \multirow{3}{*}{ Pollution degree } & \multicolumn{6}{|c|}{ Winter } & \multicolumn{6}{|c|}{ Spring } & \multicolumn{6}{|c|}{ Summer } \\
\hline & & & \multicolumn{2}{|c|}{ Home 1} & \multicolumn{2}{|c|}{ Home 2} & \multicolumn{2}{|c|}{ Home 3} & \multicolumn{2}{|c|}{ Home 1} & \multicolumn{2}{|c|}{ Home 2} & \multicolumn{2}{|c|}{ Home 3} & \multicolumn{2}{|c|}{ Home 1} & \multicolumn{2}{|c|}{ Home 2} & \multicolumn{2}{|c|}{ Home 3} \\
\hline & & & $\mathrm{M}$ & $\mathrm{E}$ & $\mathrm{M}$ & $\mathrm{E}$ & $\mathrm{M}$ & $\mathrm{E}$ & $\mathrm{M}$ & $\mathrm{E}$ & $\mathrm{M}$ & $\mathrm{E}$ & $\mathrm{M}$ & $E$ & $\mathrm{M}$ & $\mathrm{E}$ & $\mathrm{M}$ & $\mathrm{E}$ & $M$ & $E$ \\
\hline \multirow{5}{*}{ Bacteria } & $<50$ & Very Low & & & & & & & & & & & & & & & & & & \\
\hline & $50-100$ & Low & & & & & & & & & & & & & & & & & & \\
\hline & $100-500$ & İntermediate & + & & + & + & + & & & & + & + & + & + & & & + & + & & + \\
\hline & $500-2000$ & High & & + & & & & + & + & + & & & & & + & + & & & + & \\
\hline & $>2000$ & Very High & & & & & & & & & & & & & & & & & & \\
\hline
\end{tabular}

\begin{tabular}{|c|c|c|c|c|c|c|c|c|c|c|c|c|c|c|c|c|c|c|c|c|}
\hline \multirow{3}{*}{$\begin{array}{l}\text { Group of } \\
\text { microbes }\end{array}$} & \multirow{3}{*}{$\begin{array}{l}\text { Range of } \\
\text { values } \\
\left(\mathrm{CFU} / \mathbf{m}^{3}\right)\end{array}$} & \multirow{3}{*}{ Pollution degree } & \multicolumn{6}{|c|}{ Winter } & \multicolumn{6}{|c|}{ Spring } & \multicolumn{6}{|c|}{ Summer } \\
\hline & & & \multicolumn{2}{|c|}{ Home 1} & \multicolumn{2}{|c|}{ Home 2} & \multicolumn{2}{|c|}{ Home 3} & \multicolumn{2}{|c|}{ Home 1} & \multicolumn{2}{|c|}{ Home 2} & \multicolumn{2}{|c|}{ Home 3} & \multicolumn{2}{|c|}{ Home 1} & \multicolumn{2}{|c|}{ Home 2} & \multicolumn{2}{|c|}{ Home 3} \\
\hline & & & $\mathrm{M}$ & $E$ & $\mathrm{M}$ & $E$ & M & $E$ & $\mathrm{M}$ & $E$ & $\mathrm{M}$ & $E$ & M & $E$ & $\mathrm{M}$ & $E$ & $\mathrm{M}$ & $E$ & $\mathrm{M}$ & $E$ \\
\hline \multirow{5}{*}{ Fungi } & $<25$ & Very Low & & & & & & & & & & & & & & & & & & \\
\hline & $25-100$ & Low & + & + & + & + & + & + & & & & & + & + & & & + & & + & \\
\hline & $100-500$ & İntermediate & & & & & & & + & + & + & + & & & + & + & & + & & + \\
\hline & $500-2000$ & High & & & & & & & & & & & & & & & & & & \\
\hline & $>2000$ & Very High & & & & & & & & & & & & & & & & & & \\
\hline
\end{tabular}

*M: Midday, E: Evening 
Table 5. Indoor/Outdoor (I/O) ratios for the measured bacteria and fungi concentrations

\begin{tabular}{|c|c|c|c|c|c|c|}
\hline \multirow{2}{*}{$\begin{array}{c}\text { I/O Ratios of } \\
\text { Bacteria Results }\end{array}$} & \multicolumn{2}{|c|}{ Winter } & \multicolumn{2}{|c|}{ Spring } & \multicolumn{2}{|c|}{ Summer } \\
\hline & Midday & Evening & Midday & Evening & Midday & Evening \\
\hline \multicolumn{7}{|c|}{ Home 1} \\
\hline Hallway & 0.96 & 3.93 & 0.52 & 1.22 & 1.06 & 0.38 \\
\hline Living Room & 0.99 & 0.75 & 0.24 & 0.92 & 0.42 & 0.26 \\
\hline Bedroom & 0.42 & 3.04 & 0.42 & 0.59 & 0.68 & 0.33 \\
\hline Kitchen & 0.52 & 1.03 & 0.36 & 0.82 & 0.35 & 0.57 \\
\hline Bathroom & 0.66 & 0.60 & 0.58 & 0.85 & 0.50 & 1.19 \\
\hline \multicolumn{7}{|c|}{ Home 2} \\
\hline Hallway & 0.76 & 0.55 & 1.47 & 1.62 & 0.75 & 0.83 \\
\hline Living Room & 1.12 & 0.46 & 0.41 & 1.00 & 0.39 & 0.17 \\
\hline Bedroom & 1.65 & 0.45 & 0.18 & 0.69 & 0.41 & 0.31 \\
\hline Kitchen & 0.16 & 0.92 & 1.76 & 3.00 & 0.09 & 0.50 \\
\hline Bathroom & 0.16 & 0.74 & 0.29 & 0.31 & 0.29 & 0.85 \\
\hline \multicolumn{7}{|c|}{ Home 3} \\
\hline Hallway & 0.16 & 1.24 & 0.29 & 2.18 & 0.34 & 5.42 \\
\hline Living Room & 0.11 & 3.49 & 0.67 & 0.77 & 0.24 & 2.25 \\
\hline Bedroom & 0.10 & 2.56 & 0.82 & 2.41 & 1.18 & 3.83 \\
\hline Kitchen & 0.10 & 0.38 & 1.49 & 0.68 & 0.39 & 1.50 \\
\hline Bathroom & 0.10 & 1.44 & 2.33 & 2.64 & 0.80 & 9.08 \\
\hline \multirow{2}{*}{$\begin{array}{l}\text { I/O Ratios of } \\
\text { Fungi Results }\end{array}$} & \multicolumn{2}{|c|}{ Winter } & \multicolumn{2}{|c|}{ Spring } & \multicolumn{2}{|c|}{ Summer } \\
\hline & Midday & Evening & Midday & Evening & Midday & Evening \\
\hline \multicolumn{7}{|c|}{ Home 1} \\
\hline Hallway & 0.06 & 2.22 & 0.62 & 0.32 & 0.38 & 0.52 \\
\hline Living Room & 0.19 & 1.44 & 0.33 & 0.21 & 0.40 & 0.33 \\
\hline Bedroom & 0.13 & 1.11 & 0.95 & 0.47 & 0.47 & 0.13 \\
\hline Kitchen & 0.00 & 0.56 & 0.46 & 0.58 & 0.35 & 0.33 \\
\hline Bathroom & 0.13 & 0.67 & 0.16 & 0.33 & 0.58 & 0.45 \\
\hline \multicolumn{7}{|c|}{ Home 2} \\
\hline Hallway & 0.04 & 0.21 & 0.06 & 0.38 & 0.61 & 0.13 \\
\hline Living Room & 0.20 & 0.04 & 0.02 & 0.23 & 0.36 & 0.18 \\
\hline Bedroom & 0.09 & 0.04 & 0.03 & 0.05 & 0.30 & 0.29 \\
\hline Kitchen & 0.25 & 0.96 & 0.80 & 0.70 & 0.24 & 0.41 \\
\hline Bathroom & 0.02 & 0.29 & 0.02 & 0.06 & 0.18 & 0.13 \\
\hline \multicolumn{7}{|c|}{ Home 3} \\
\hline Hallway & 0.04 & 0.20 & 0.04 & 0.07 & 0.14 & 1.26 \\
\hline Living Room & 0.12 & 0.67 & 0.07 & 0.05 & 0.20 & 0.19 \\
\hline Bedroom & 0.04 & 0.20 & 0.12 & 0.31 & 0.20 & 0.65 \\
\hline Kitchen & 0.44 & 0.13 & 0.08 & 0.12 & 0.14 & 0.90 \\
\hline Bathroom & 0.00 & 0.13 & 0.09 & 0.06 & 0.20 & 0.23 \\
\hline
\end{tabular}


The scatterplots of bacteria versus fungi concentrations for all homes show positive linear relationships for winter season (Fig. 4).

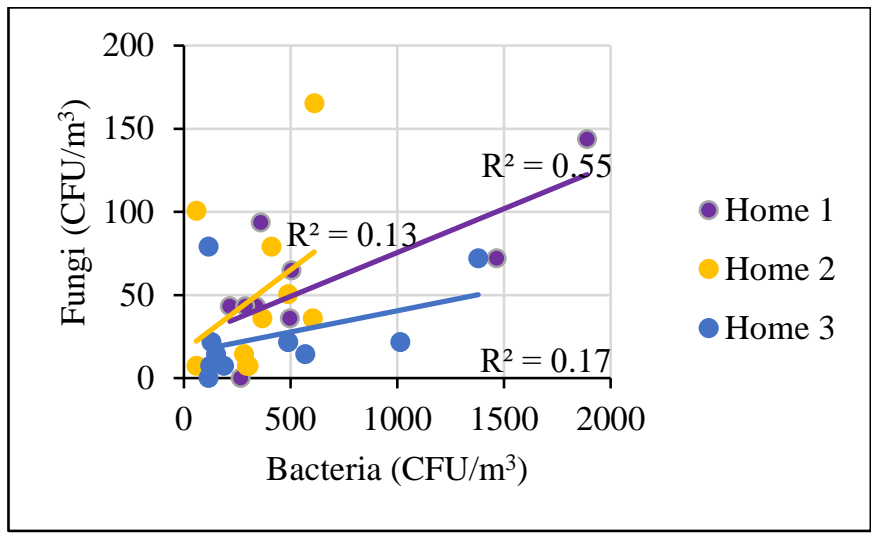

Figure 4. Correlation between the fungi and bacteria concentrations of the selected homes in the winter season

The scatterplots of bacteria versus fungi concentrations for spring season are given in Fig. 5. The highest relationship was observed for Home $2\left(\mathrm{R}^{2}=0.66\right)$.

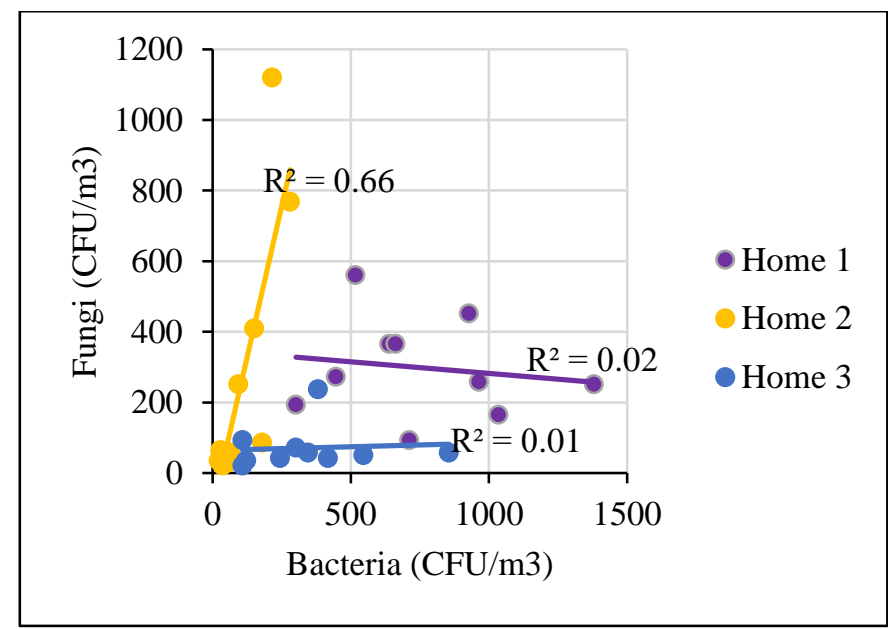

Figure 5. Correlation between the fungi and bacteria concentrations of the selected homes in the spring season

Weak relationships were found for all homes in the summer season (Fig. 6). In general, weak bacteria-fungi relationships were observed in all seasons except for winter season at Home 1 and spring season at Home 2.

The presence of nutrients (dirt, wood, paper, paint, etc.), the amount of oxygen and the amount of light have an impact on the growth of microbiological pollutants in the indoor environments. Fungi and bacteria are the most often found microorganisms indoors. Toxic substances like mycotoxins or volatile organic compounds may be produced by fungus and can become airborne with the spores they produce (Menteşe \& Güllü, 2009).

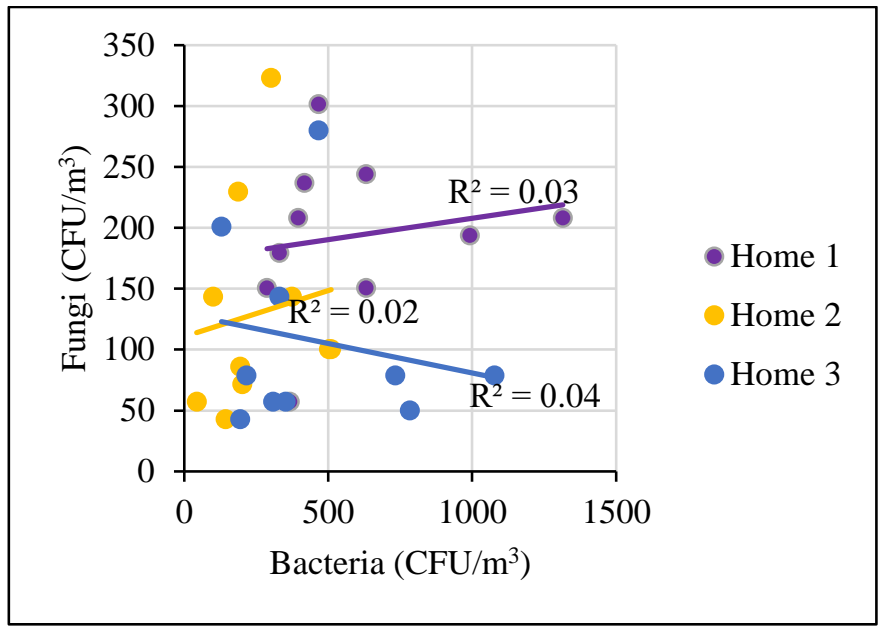

Figure 6. Correlation between the fungi and bacteria concentrations of the selected homes in the summer season

In Table 4, the measurement results of this study were evaluated by using European Commission's 1993 sanitary standards for non-industrial facilities and households (Fekadu \& Getachewu, 2015). Based on the given categorization, "very high" pollution degree was not achieved in any measurement period. In general, the results were between "low" and "high" pollution degrees (Table 4).

The highest I/O ratio for bacteria was found in the bathroom of Home 3 in the summer-evening measurement period while the highest I/O fungi ratio was obtained in the hallway of Home 1 in the winter-evening period (Table 5).

\section{Conclusions and Recommendations}

In consequence of the pandemic, people spend most of their time at homes. For this reason, many people are more exposed to air pollution indoors than outdoors, and accordingly they are more affected.

In this study, microbiological measurements were performed in three different homes selected in Eskişehir, Turkey. In general, seasonal changes and characteristics of the home environments were observed to have an effect on the measured bacterial and fungal concentrations. Although the measured concentrations are not "very high" when compared with European Commission standards, some precautions such as much more ventilation of the rooms, ventilation of clothes and textiles outside, keeping carpets clean and dry, keeping the humidity and temperature of the environments at optimum values should be taken at homes.

\section{References}

Aghlara, E. (2017). "Levels of bioaerosols in indoor and outdoor environments and resource detection," Ph.D. thesis. Environmental Engineering. Hacettepe Univ. Ankara.

Agle, E., \& Galbraith, S. (1991). Building air quality: A guide for building owners and facility managers (Issues 91-114). US Government Printing Office.

Alwakeel, S. S. (2008). Indoor fungal and bacterial contaminations on household environment in riyadh, Saudi Arabia. Saudi Journal of Biological Sciences, 15(1), 113119.

Demirel, G., Özden, Ö., Döğeroğlu, T., \& Gaga, E. O. (2014). 1244 
Personal exposure of primary school children to BTEX, $\mathrm{NO}_{2}$ and ozone in Eskişehir, Turkey: Relationship with indoor/outdoor concentrations and risk assessment. Science of the Total Environment, 473, 537-548.

Diffey, B. L. (2011). An overview analysis of the time people spend outdoors. British Journal of Dermatology, 164(4), 848-854.

Fabian, M. P., Miller, S. L., Reponen, T., \& Hernandez, M. T. (2005). Ambient bioaerosol indices for indoor air quality assessments of flood reclamation. Journal of Aerosol Science, 36(5-6), 763-783.

Fekadu, S., \& Getachewu, B. (2015). Microbiological assessment of indoor air of Teaching hospital wards: a case of Jimma University specialized hospital. Ethiopian Journal of Health Sciences, 25(2), 117-122.

Gönüllü, M. T., Bayhan, H., Avşar, Y., \& Arslankaya, E. (2002). YTÜ Şevket Sabancı Kütüphane Binası iç ortam havasındaki partiküllerin incelenmesi. Yıldız Teknik Üniversitesi.

Hu, D., Wang-Li, L., Simmons III, O. D., Classen, J. J., Osborne, J. A., \& Byfield, G. E. (2014). Bioaerosol Concentrations and Emissions from Tunnel-Ventilated High-Rise Layer Houses in North Carolina. Transactions of the ASABE, 57(3), 915925.

Jones, B. L., \& Cookson, J. T. (1983). Natural atmospheric microbial conditions in a typical suburban area. Applied and Environmental Microbiology, 45(3), 919-934.

Klepeis, N. E., Nelson, W. C., Ott, W. R., Robinson, J. P., Tsang, A. M., Switzer, P., Behar, J. V, Hern, S. C., \& Engelmann, W. H. (2001). The National Human Activity Pattern Survey (NHAPS): a resource for assessing exposure to environmental pollutants. Journal of Exposure Science \& Environmental Epidemiology, 11(3), 231-252.

Lee, J. H., Ahn, K. H., \& Yu, I. J. (2012). Outbreak of bioaerosols with continuous use of humidifier in apartment room. Toxicological Research, 28(2), 103-106.

Lee, S.-C., Guo, H., Li, W.-M., \& Chan, L.-Y. (2002). Intercomparison of air pollutant concentrations in different indoor environments in Hong Kong. Atmospheric Environment, 36(12), 1929-1940.
Menteşe, S., \& Güllü, G. (Mayıs 2009). Organik bileşiklerin farklı iç ortamlardaki seviyeleri. IX. Ulusal Tesisat Mühendisliği Kongresi (TESKON). İzmir, Turkey, pp.673-679.

Menteşe, S., Tuğba, B., Mutlu, M. B., Özdemirpençe, S. S., Nişanc1, S. Y., Palaz, E., Çetin, B., Taşdibi, D., Selçuk, B., \& Karagöz, S. (Nisan 2013). Havadan Kaynaklı Bakteri Seviyesinin Çanakkale'deki Ev, Yurt Ve Okullarda Mekansal Değişimi. 11. Ulusal Tesisat Mühendisliği Kongresi. İzmir, Turkey, pp.1865-1872.

Nazaroff, W. W. (2016). Indoor bioaerosol dynamics. Indoor Air, 26(1), 61-78.

WHO (2008). Development of air quality guidelines for indoor air quality: dampness and mould: report on a working group meeting, Bonn, Germany 17-18 October 2007. Copenhagen: WHO Regional Office for Europe.

WHO (2009). Children's Health and the Environment. WHO Training Package for the Health Sector-World Health Organization.

Ren, P., Jankun, T. M., Belanger, K., Bracken, M. B., \& Leaderer, B. P. (2001). The relation between fungal propagules in indoor air and home characteristics. Allergy, 56(5), 419-424.

Shiaka, G. P., \& Yakubu, S. E. (2013). Comparative analysis of airborne microbial concentrations in the indoor environment of two selected clinical laboratories. IOSR J Pharm Biol Sci (IOSR-JPBS), 8(4), 13-19.

Siersted, H. C., \& Gravesen, S. (1993). Extrinsic allergic alveolitis after exposure to the yeast Rhodotorula rubra. Allergy, 48(4), 298-299.

Stetzenbach, L. D. (1998). Microorganisms and indoor air quality. Clinical Microbiology Newsletter, 20(19), 157-161.

Yassin, M. F., \& Almouqatea, S. (2010). Assessment of airborne bacteria and fungi in an indoor and outdoor environment. International Journal of Environmental Science \& Technology, 7(3), 535-544. 